\title{
ROMAN MEDICINE AND THE LEGIONS: A RECONSIDERATION*
}

\author{
by
}

\author{
JOHN SCARBOROUGH
}

Although all general histories of medicine make reference to skilled doctors in the Roman legions, the specialized secondary literature on the subject is not plentiful. ${ }^{1}$ Garrison, Jacob, Haberling, and Richmond, among others, are mentioned when one speaks of works on the question of medicine in the Roman legions. Apparently the problem of doctors in the legions has been considered settled.

Previous discussions generally argue that the legion was supplied with skilled medical care. The evidence noted consists of numerous inscriptions found throughout the empire, which mention in one military context or another, a medicus or a iatros. According to the usual view the reliefs on the Column of Trajan reinforce the inscriptional evidence of trained doctors in the legions. Normally omitted from detailed discussion is the broader perspective presented by literary sources. Like all things Roman, the legions must be considered as a part of the general cultural matrix, and they cannot be separated in a historical analysis from the society from which they took their origin. Also we must be exceedingly wary of equating twentieth-century medicine with the practice and theory of medicine in the Roman Empire. As Sigerist has so carefully and pointedly observed, modern conceptualizations of medicine,

* The following abbreviations are used in this study: CIL: Corpus Inscriptionum Latinarum. IGRR: Inscriptiones Graecae ad res Romanas pertinentes. OGIS: Orientis Graecae Inscriptiones selectae.

1 The bibliography on the Roman medicus and related problems includes the following: $O$. Jacob, 'Le service de santé dans les armés romaines', $L$ 'Antiquité classique, 1933, 2, 313-29 (further citations as 'Jacob'); W. Haberling, 'Die altrömischen Militărărzte', Veröff. Geb. MilitSanitWes., 1910, 42, 79 pp. (cited hereafter as 'Haberling'); H. Droysen, 'Das Militärmedizinalwesen der römischen Kaiserzeit', Dt. militärärztl. $Z$., 1874, 3, 38-42; H. Fröhlich, 'Ueber die Kriegschirurgie der alten Römer', Arch. klin. Chir., 1880, 25, 315-19; H. Liebl, 'Zum Sanitätswesen im römischen Heere', Wiener Studien, 1902, 24, 381-85; J. Stuart (ed.), 'Was the Roman army supplied with medical officers?', Archaeological Essays, Edinburgh, 1872, 197-227; J. Elliott, 'Medical service with the Roman legions', N. Z. med. J., 1949, 48, 585-90; I. A. Richmond, 'The Roman army medical service', Univ. Durham med. Gaz., June 1952, 2-6.

For developments in the Later Empire, see G. Pezzi, "Alessandro di Tralles visto da un medico militare', Ann. Med. nav. colon., 1949, 54, 154-63. The general context is suggested by $H$. Barnes, 'On Roman medicine and Roman medical inscriptions found in Britain', Proc. Roy. Soc. Med., 1914, 8, 71-87; and R. Briau, 'Mémoire sur l'assistance médicale chez les Romains', Mém. prés. div. Sav. Acad. Inscrip. Belles-Lettres, 1874, 8, 121-210; and Du Service de Santé militaire chez les Romaines, Paris, 1866. General development of military medicine is traced in F. H. Garrison, Notes on the History of Military Medicine, Washington, 1922 (pp. 47-77 for discussion of Roman medicine).

All of these secondary studies attest to the major importance of inscriptions for their conclusions. One needs to note the broad span of time that the studies cover and the vast geographical variance that may have been present in the actual practice of medicine in the legions. Our evidence is such that general conclusions can be drawn for the 600-year development of legionary medicine, but inscriptional finds are, for example, common only in the period of the Early Empire. Literary sources are almost as scanty and scattered for the topic, and although one would like to clarify certain patterns of medical practice in a given period as distinguished from other periods, the paucity of firm evidence presents problems. Parker and Starr have been able to show directions of development in the legion and the Roman navy, but medical practice, as such, can only be seen clearly in the numerous inscriptions of the Early Empire. When the inscriptional evidence is filled out with important references from Celsus, Cicero, Caesar, Velleius Paterculus, Plutarch, and Vegetius, we can formulate a conclusion for military medicine in the first two centuries of the Empire. 


\section{Roman Medicine and the Legions}

science, and society often do not apply to antiquity. So it is with consideration of the medicus in the Roman legion.

First, to trace Roman concepts of medical care in the legions, a brief consideration of practice as it emerged in the Roman Republic is appropriate.

The sources which relate the early military history of Rome and her arduous conquest of the Italian peninsula have few references to medical matters in the phalanxlegion as it evolved in the Republic. Medical care was minimal and there was little provision for the wounded. The Romans adapted new techniques on an ill-defined scale and some Hellenistic practices became predominant as time went on. The evolution of medical practice in the legions resembled closely the development of medicine in Roman society at large. The crude medicine practised by the soldiery upon themselves was designed to get the warrior back into battle as quickly as possible. Care was taken of the wounded by the commanding general, and the prevailing attitude caused one modern authority to comment that the Roman army had as its major characteristic a sort of 'stoicism' which allowed the soldiers to be unworried about medical aid. ${ }^{2}$

A good general was one who billeted his wounded in a friendly town or fortress. ${ }^{8}$ The soldier was dependent upon his fellows for aid and this medicine resembled that used by the Roman civilian who practised a sort of 'folk' medicine." The contention that there was a voluntary medical corps with the legions which treated wounds and diseases has no foundation on the available evidence, especially from the Republic. ${ }^{5}$ The problem of the wounded would not be too important if the Roman legion won its battles; those who were victorious in ancient warfare usually did not lose many men, whereas those who lost normally lost everything. ${ }^{\circ}$

As the Romans came to know the Hellenistic world, the Roman general adopted a practice that was common among Hellenistic commanders. A personal physician often accompanied the general on the battlefield. ${ }^{7}$ On the other hand, before a definite reference from Cicero, there is little indication that the common soldier had access to medical care. ${ }^{8}$ The soldiers of the higher ranks, who were of aristocratic extraction, had a 'refreshment retreat' in their tents which they could use and to which they could retire when they became tired or wounded. The Romans apparently regarded the 'retreat' as a portable relaxation point rather than a special place to

\footnotetext{
Dionysius of Halicarnassus, IX, 50. 5; the description of soldiers putting on themselves fake wound dressings so as to escape fighting; it would seem that soldiers were accustomed to put on their own dressings. Polybius, III, 66. 9; Publius cares for himself and his wounded. Plutarch, Antony, 43. 1; Antony gives sympathy to his wounded soldiers; they in turn beg him teporreúviv aúrov. Plutarch, Crassus, 25. 5; the soldiers are pictured as attempting to pull the barbed Parthian arrows from their own wounds. So-called stoicism: Jacob, 317-18.

Livy, IV, 39; XXXVII, 33; XL, 33.

- Dionysius of Halicarnassus, IX, 50. 5; the reference (note 2 above) shows that the soldiers were skilled in wound dressing if they thought they could deceive with their own. Cato, 114-15, 127, 156-60, indicates what sort of 'medicine' was known by the Roman citizens in the Republic, and Roman citizens, of course, served in the legions.

C. Lamarre, De la milice Romaine, Paris, 1870, 352, states this view.

- F. E. Adcock, The Greek and Macedonian Art of War, Berkeley, 1962, 14-28, 64-98, and The Roman Art of War under the Republic, Cambridge, 1963, 3-28. H. M. D. Parker, Roman Legions, Cambridge, 1961, 1-46.

Plutarch, Marius, 6. 3; Caesar, 34. 3; Pompey, 2. 5-6.

- Cicero, Tusculan Disputations, II, 16. 38.
} 


\section{John Scarborough}

go for the treatment of wounds. ${ }^{9}$

The Roman consul borrowed some of the devices that are seen in Xenophon ${ }^{10}$ and he adopted them with Roman forthrightness; some of the troops functioned as a medical staff as the need arose. Roman consuls were often skilled wound dressers in their own right and their knowledge of such matters stemmed from long years in the legions. ${ }^{11}$

Cicero tells us that the experienced soldier was confident of treatment in the field but the novice despaired at the slightest hurt. ${ }^{12}$ His use of medicus is the first definite reference we have of medical aid for the legionary. The imprecise Latin, however, leaves the modern reader with the impression the medicus was just another soldier, but one who had been judged experienced among the legionaries in problems of wound dressing. ${ }^{13}$ Usually the term medicus was attached almost indiscriminately to anyone who appeared as if he knew something of medicine, and Apollo medicus commanded a large following with a set of quasi-medical sayings. ${ }^{14}$

The stereotype of the military physician, as the Roman thought of him, is presented by Virgil, and the figure fits the evidence that we possess for both the military and civilian modes of life in the late Republic and the Early Empire.

At this point, Iapis, the son of Iasus, came up: this man

Was especially dear to Apollo, who, seized by intense passion

For him, had delightedly offered him his own arts, his own powers

Of divination, of music, of shooting the swift-flying arrow.

Iapis, to lengthen the life of a father desperately ill

Elected the knowledge of healing herbs, the science of medicine

Choosing to practice an art which has little réclame, in obscurity. ${ }^{16}$

Virgil gives clues of the common attitude about a soldier's troubles, and the military man was admired for the amount of physical punishment he could take. Virgil echoes some of the callous opinions that strike the modern reader in the fragments of Ennius. ${ }^{16}$

Caesar has many passages which allow us to determine whether or not an official medical corps was available to the Roman legionary. His regard for the safety and well-being of his trusted legions is apparent in his writing. Concern for individuals

- Plutarch, Aemilius Paulus, 22. 1; used for celebration of victory. Brutus, 4. 4; his tent contained refreshment for the tired gereral.

${ }^{10}$ Xenophon, Anabasis, III, 4. 30: 'They appointed eight physicians for there were many wounded.'

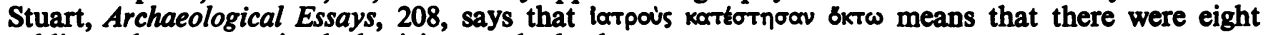
soldiers who were trained physicians and who knew surgery.

${ }_{11}$ Polybius, III, 66. 9; see note 2 above. That a general would 'care for himself and his wounded' indicates that the tradition was strong.

${ }^{18}$ Cicero, Tusculan Disputations, II, 16. 28. Silius Italicus, VI, 68-69; the wounded soldier expects someone to come bind up his wounds. Caesar, African War, 21 ; notes that soldiers have their wounds dressed. These indicate that the customary use of the medicus is well established, and that they are looked to by their fellow legionaries for their specialized function.

${ }_{18}$ Medicus as used in Latin literature takes on a variety of meanings. In Silius Italicus, III, 300, it has a definite connotation of magic. In Virgil, Georgics, III, 455, and Ovid, Tristia, V, 6. 12, the term denotes merely 'healing ability'. Cicero, Pro Cluentio, XXI, 57, Suetonius, Nero, 37, Plautus, Menaechmi, V, 3. 9, and Juvenal, II, 13, use medicus to signify what we would term a physician or a surgeon. Pliny XXIX, 6. 13, attempts to define his subject by referring to a vulnerarius ('wound specialist').

14 Macrobius, Saturnalia, I, 17. 15. Virgil, Aeneid, XII, 391-97.

16 Virgil, Aeneid, XII, 391-97. trans. C. Day Lewis, Virgil's Aeneid, New York, 1953, 301.

16 Ennius, frgs. 140, 284, 285, 609. (ed. Vahlen). 


\section{Roman Medicine and the Legions}

serving under his standards marks Caesar as one of the great leaders of men, and a passage from the Gallic War, which relates to our discussion, points this up well.

One of the sick men who had been left behind with the guard was Publius Sextius Baculus. He had served under Caesar as a senior centurion, and he has been mentioned in regard to previous battles. He had already been five days without food. Now unsure about his own safety, and that of the others, he went forth from his tent unarmed ... Sextius fell unconscious as he was seriously wounded, and he was just barely saved by being dragged from the scene from hand to hand. ${ }^{17}$

Caesar praises the man's valour and this kind of eulogy is repeated throughout the Gallic War. ${ }^{18}$ It seems odd, however, that although Caesar reports numbers of the wounded and the condition of some of the wounded, he fails to account for how they might have been treated. ${ }^{19}$ Jacob argues that since Caesar does not bother to talk of this matter, the wounded were taken care of by a medical corps that Caesar took for granted. ${ }^{20}$ A sounder conclusion would be that there was a kind of de facto medical service of soldier-medici which obviated notice.

An official medical service was not a part of the Roman consul's planning on the field of battle. The account given by Plutarch of the disaster at Carrhae shows this clearly. ${ }^{21}$ With an elaborate expedition such as Crassus prepared against Parthia, a medical staff would have been included if it was customary to have an official service on the battlefield. Again we can note that the generals supplied themselves with physicians who attended to their personal needs. ${ }^{22}$ Caesar recognized the value of billeting his wounded in a safe spot so that they might return to battle, and his system of evacuation of his wounded shows considerable foresight. ${ }^{23}$ The major characteristic of the references that Caesar gives us about his sick and wounded is one of praise for the endurance of his troops, and great hints of the typical, coldblooded, 'stoic' attitude of the Roman legionary.

Thus by the end of the Republic, Roman military medicine was modelled to a certain degree upon precedents common in the Greek armies of the Hellenistic period. The consul and the noble elements of the legion supplied themselves with personal medical care, but the legionary was left in the care of the medici. ${ }^{24}$ The superb discipline of the Roman legion and its winning record kept the usual incidence of wounded low, but the legionary, like his enemies, suffered from the devastations of disease until the use of the valetudinarium, and sanitary measures became commonplace in the Empire. ${ }^{25}$

Inscriptions from the Empire, as well as further literary references, indicate the unofficial basis of medical care in the legions. In speaking of the primorum ordinum

${ }^{17}$ Caesar, Gallic War, VI, 38. 1-4.

18 e.g. Gallic War, IV, 12. 4; V, 35. 6.

10 Gallic War, I, 26. 5; V, 52. 2 and 35. 8; VI, 38. 1-4. Plutarch, Caesar, 16.

20 Jacob, 326.

21 Plutarch, Crassus, 24-25.

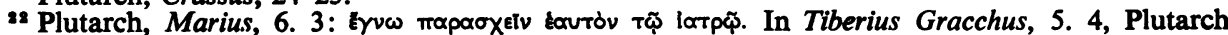
notes that camp followers include what are probably medical attendants: \&vEv $\theta \varepsilon p \alpha \pi \varepsilon i \alpha s$ kal Tळv $\varepsilon \xi \omega$

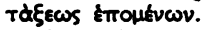

${ }_{23}$ Civil War, III, 78. 2. African War, 21.

24 Velleius Paterculus, II, 114. 3 (by implication). Tacitus, Histories, II, 45: 'Isdem tentoriis alii fratrem, alii propinquorum fovebant.'

${ }^{25}$ Caesar, Civil War, III, 87. 2. 


\section{John Scarborough}

as being a select group of century commanders whom he used as an informal consultation committee, Caesar provides a key to explain the often occurring inscriptional medicus ordinarius. ${ }^{26}$ Since Caesar's council was one of men taken from the ranks and distinctly one of an informal nature, the medicus ordinarius, medicus cohortis, and the medicus legionis functioned on the same basis. The inscriptions show that this position was one of great respect, but that the individual so named was first a soldier in his duties, not a physician. ${ }^{27}$ It is to the Romans' credit that they recognized the need for such a service, but the solution was not a medical corps whereby trained physicians became a part of the army. The response to the problem of proper care for the sick and the wounded in the legions took the form that the Roman would understand and he thought that it was effective for the need as it was demonstrated. The wounded were cared for, as far as possible on the field, and the transportable sick were placed in valetudinaria along with the more severely wounded. The Romans clearly distinguished in the legions between the treatment of the 'sick' and the 'wounded'.

Examples from the inscriptions and from archaeological excavation illustrate the approach. An inscription found in the vicinity of Hadrian's Wall tells in terse terms of the gratitude felt by the soldiers of the first Tungrian Cohort for one Ancius Ingenuus, who had died at the age of twenty-five. His memorial tablet was embellished to an extent that might not be expected, and he is styled medicus ordinarius. ${ }^{28}$ This indicates his status as one of the ranks, but his status of great respect among his fellow soldiers. ${ }^{29}$ Compassion was as highly prized among the Roman legionaries as it is in any age. Titus Claudius Hymnus, medicus legionis to the XXI Claudia, is commemorated in a similar fashion. ${ }^{30}$ The Cohors IV Praetoria gives us an interesting example of a medicus cohortis who erected a memorial to himself and to his dependents. ${ }^{31}$ The tone of the inscription allows the modern viewer to observe what

26 Caesar, Gallic War, I, 41. 3. Parker, Roman Legions, 32.

27 Haberling, 26, notices this problem '... trotzdem er [Deciminus: medicus ordinarius legionis in Lower Germany (CIL, III, 4279)] aktiver soldat war . . ., but quickly passes over it to other matters. Haberling's study has a magnificent summary 'proving' that physicians were in the legions.

The informal status of the title is firmly indicated by the multiplicity of designations of the medici in the legions. CIL, XIII, 7943 (M. Sabinianus Quictus, medicus miles of the I Minervia at Bonn). CIL, III, 143475 (T. Aurelius Numerius, medicus legionis of the XXII Primigenia from Aquincum in Hungary). CIL, III, 5959 (Ulpius Lucilianus, medicus ordinarius of the III Italica from Lambaesis in Algeria). CIL, III, 6532 (an anonymous medicus [?] ordinarius legionis of the III Italica from Castra Regina [Regensberg]). CIL, VIII, 18314 (Papirius Aelianus, medicus ordinarius legionis of the III Augusta from Lambaesis). CIL, III, 3413 (Marcus Marcellus, medicus of an undetermined legion from Aquincum). This inscription is an important one, clearly showing the status of the medicus and how the probable system functioned under the direction of a superior officer: 'Asclepio et Hygiae Mar[cius] Marcellus, med[icus] sub c[ur] a[gente?] P. Va(1[erio]) Praesent[e] evoc[ato] v[otum] s[olvit] l[ibens] m[erito].' CIL, III, 14349 (Caius Nundinius Optervius, medicus stipendiis of an undetermined legion from Aquincum). Greek inscriptions tell another side of the story. IGRR, 1 . 1212, shows a Greek physician functioning in the II Trajana from Thebae in Egypt (dated A.D. 147). $I G R R, 1.1361$ (OGIS, 207), indicates that an Egyptian temple physician was servicing the XXII Deiotariana in the Hellenistic tradition. In the Latin inscriptions, other titles abound. CIL, VI, 2532 (Rome): medicus clinicis cohortis. CIL, XIII (Lugdunum): medicus castrensis, are but two of many varieties.

as CIL, VII, 690.

10 The individuals who function as medici in the auxilia show their non-Roman origins (names listed in Haberling, 73), but their designations follow the pattern noted for the legions. e.g. CIL, III, $4279,5959,6532$; XIII, 6621, 7094, 7415.

${ }^{\circ 0} \mathrm{CIL}, \mathrm{XIII}, 2308$.

31 CIL, VI, 2532. 


\section{Roman Medicine and the Legions}

could be called 'scientific magic' in the taking of vows in connection with the function of the medicus in the legions. The Roman navy had its own variety of 'doctor', termed the medicus duplicarius, and his skill was limited..$^{32}$

The great number of inscriptions indicate the medicus to be very common, particularly in the frontier posts. We can assume that the medici were on hand at most points to render what aid they could, and probably the newer medici learned their medicine from the 'senior' medici present in the legion.

As the Roman legion developed efficiency and learned to deal with isolated locations which made it impossible for the wounded to be evacuated to a safe Roman fort or allied town, it began to build valetudinaria which would serve this function. These structures were the Roman answer to isolation and proved to be an integral part of the castra, especially on the frontier. ${ }^{33}$ Here the medici, experienced as they were in the wounds of war, treated their comrades. The legionary hospitals were carefully planned and show insight into drainage problems with regard to sanitary conditions. ${ }^{34}$ Roman engineering skill is apparent and one must admire these islands of hope placed at the edge of the civilized world. Again it should be emphasized that the valetudinaria argue for the medical care of the sick as the Roman thought of them in contradistinction from the wounded. They indicate that the Roman army was following good military practice by providing a place for the sick and the transportable wounded near to the source of manpower need. In an age where geographical distances were fantastic, this points to the element of genius inherent in Roman military organization.

Literary evidence spanning the entire course of the Roman Empire points firmly to the lack of an organization of an official medical service which would administer to the common soldier. In his praise of Tiberius, Velleius Paterculus reveals the presence of medical care for the officers of the legions, but not for the common soldier.

And now for a detail which in telling may lack grandeur, but is most important by reason of the true and substantial personal qualities it reveals and also of its practical service . . . a thing most pleasant as an experience and remarkable for the kindness it displayed. Throughout the whole period of the German and Pannonian War there was not one of us, or of those either above or below our rank, who fell ill without having his health and welfare looked after by Caesar with as much solicitude indeed as though this were the chief occupation of his mind preoccupied though he was by his heavy responsibilities. There was a horsed vehicle for all those who needed it; his own litter was at the disposal of all, and I, among others, have enjoyed its use. Now his physicians, now his kitchen, now his bathing equipment, brought for this one purpose for himself alone, ministered to the comfort of all who were sick. All they lacked was their home and their domestic servants, but nothing else that friends at home could furnish or desire for them. ${ }^{35}$

Even the aristocrat was grateful for good medical care. The passage indicates that

${ }^{32}$ CIL, VI, 3910; VII, 1144; X, 3442-44; XI, 19. A von Domaszewski, Die Rangordnung des römischen Heeres, Bonn, 1908, 15 and 45. C. G. Starr, Roman Imperial Navy, Cambridge, $1960,56$. Duplicarius merely indicates that the individual received double pay.

${ }^{33}$ The literature on the legionary hospitals is plentiful. Examples are I. A. Richmond, 'Roman Britain and Roman military antiquities', Proceedings of the British Academy, XLI (1955), 297-315 [314-315]; R. Schultze, 'Die römische Legionslazarette in Vetera und anderen Legionslagern', Bonner Jahrbücher, 1934, 139, 54-63, and C. Koenen, 'Beschreibung von Novaesium', Bonner Jahrbücher, 1904, 111-112, $97-242(5-6,28,53-54,180-82)$.

is Richmond, 314-15. Schultze, 56-58.

so Velleius Paterculus, II, 114. 1-3. Trans. F. W. Shipley (Loeb). 


\section{John Scarborough}

trained physicians available for the legion at large were rare and that Tiberius followed the practice of the best Roman generals. Such care was not usual and the soldiers received the ministrations of the medici in their own ranks. In another context Tacitus crisply notes the thankfulness of the soldiers when Agrippina went among the wounded and acted as a nurse, dressing the wounds and giving clothing to those who needed it. ${ }^{36}$ At another point Tacitus states bluntly that the soldiers took care of their own wounds and doctored one another. ${ }^{37}$ The image of medicine in the legions shows no trained physician in attendance, and that the training of the medici consisted of experience with a common knowledge of anatomy and medicine in the day-to-day needs of the legion.

Celsus remarks that anatomy can be learned from the wounds of a soldier in battle and Galen says that the medical attendants in the German Wars were like untrained empirics not to dissect the bodies of the dead German warriors to learn something more than they knew. ${ }^{38}$ Celsus gives us a detailed account of missile injuries and this may show the level of skill attained by the best of the military medici. ${ }^{39}$ From the evidence that we have of the medicus, he gathered his craft within the legion and was not a trained physician in either the Hellenistic fashion of Galen or in the Latinized manner that Celsus suggested. ${ }^{40}$

The often-cited reliefs of a medicus treating the wounded, as depicted on Trajan's Column, reinforce the conclusions that the inscriptions and literary evidence give us. The medici treating the wounded on Trajan's Column are dressing superficial wounds and their dress is identical with that of the soldiers they are aiding. ${ }^{41}$ Trajan's Column would thus bear out the general picture: the medici were those soldiers of a legion or of an auxiliary detachment who had demonstrated their capabilities for wound dressing and a primitive surgery, but who were not trained physicians. ${ }^{42}$ This tradition reached back many centuries in Roman warfare. Whether or not the best of the Roman legionary medici consulted medical handbooks such as Celsus must remain theoretical.

Returning to further references from the literary sources, one notes the unofficial basis admitted in many cases. As time passed the soldiers seemed to have received less attention of the quality noted in the Early Empire, and the camp praefect was

3acitus, Annals, I, 69.

${ }^{87}$ Tacitus, Histories, II, 45.

38 Celsus, Prooemium, 43. Galen, XIII, 604.

30 Celsus, VII, 5.

so In another context, Galen gives a clue to the regard within the legion for the medicus. In quoting

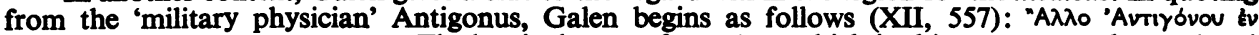

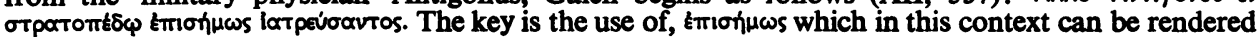
as 'approved',or 'designated', or 'marked off as'. Approval is indicated with the use of imionuos by

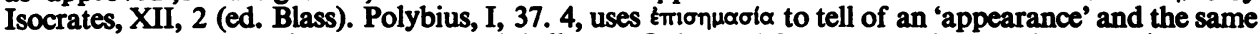
use is found in Plutarch, Numa, 22, and Sulla, 14. Galen, XIV, 661, uses the root in a passive sense

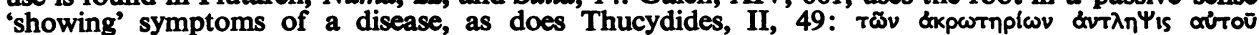

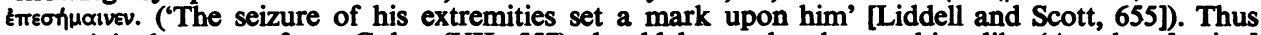
our original passage from Galen (XII, 557) should be rendered something like 'Another [recipe] of Antigonus, designated as practising medicine in a legionary camp'. This evidence links well with the inscriptional story of the 'designation' of the medicus.

"1 K. Lehmann-Hartleben, Die Traianssäule, Berlin, 1926, PI. 22 (XL-XLI). Useful is I. A. Richmond, 'Trajan's army on Trajan's Column', Papers of the British School at Rome, 13, 1-40 (13-14).

"2 Lehmann-Hartleben, P1. 22. The soldiers being treated are looking at the medici with pained resignation. 


\section{Roman Medicine and the Legions}

put in charge of what medical care they got. ${ }^{43}$ Problems with camp followers posing as medical men are seen in the following:

Let the soldier be treated by a doctor without cost, let him give nothing to the soothsayers, let them spend their time in their quarters [hospitiis] in abstinence from sensual pleasures as if for religious reasons [caste].4

... those who are most knowledgeable in military matters are of the opinion that daily exercise contributes far greater health to the soldiers than do the physicians. ${ }^{45} \ldots$

If trained physicians were present among the legions in the Later Empire, the type of medicine they practised seems to remind us of the repute of certain doctors often noted in authors of the Early Empire. ${ }^{46}$ Galen tells us that he was summoned to give proper medical treatment at the front where little apparently existed-as he saw it. Galen notes that many doctors 'talk' medicine without proving their skill."77

Scriptores historiae Augustae, Aurelian, VII, 8.

" Ibid.

as Vegetius, III, 2. In II, 10, Vegetius describes how medical care is in charge of the praefect of the camp, and this is what the evidence of $C I L$, III, 3413, would indicate (inscription quoted in note 27 above).

"s Lucian, Gout, is an example of a bitter caricature of the helpless doctor with many promises.

"Galen, XIV, 649-50. 